\title{
ПОРУШЕННЯ МІНЕРАЛЬНОГО ОБМІНУ У ПАЦІЄНТІВ ІЗ ХРОНІЧНОЮ ХВОРОБОЮ НИРОК I СЕРЦЕВО-СУДИННИМИ ЗАХВОРЮВАННЯМИ
}

\author{
МОЙСЕЄНКО В.О., МЕДВЕДЄВ Т.М. \\ Національний медичний університет імені О.О. Богомольця
}

Резюме.

Ключові слова:

Вступ. Відомо, що пацієнти з XXН частіше вмирають від серцево-судинних причин, ніж від ниркової недостатності. У цих хворих майже в 20 разів вище ризик кардіоваскулярних подій (КВП) [6]. Крім того, навіть для пацієнтів із XXH, що не потребують ниркової замісної терапії, рівень розвитку КВП набагато вище, ніж у пацієнтів, що досягають термінальної стадії ниркової недостатності і вимагають ниркової замісної терапії.

Мета. Вивчити паралелі порушення мінерального обміну у хворих 3 хронічною хворобою нирок та серцево-судинними захворюваннями.

Матеріали і методи. Огляд сучасних та зарубіжних джерел, аналіз та обговорення конкретного клінічного випадку; методики - опис, аналіз, реферування.

Результати та їх обговорення. Наведено і проаналізовано порушення мінерального обміну, зокрема кальцієво-фосфорного гомеостазу, належать до важливих ускладнень, що виникають на ранніх стадіях хронічної хвороби нирок і прогресують із погіршанням функції нирок. У низці досліджень останніх років доведено, що вищі або нижчі від цільових рівні паратгормону (ПТГ), Са, Р, Са*Р продукту тісно корелюють зі зростанням смертності нефрологічних пацієнтів [8, 9]. Так, згідно з даними J. Floege та ін. (2011), у пацієнтів із $\mathrm{V}$ стадією XXН та рівнем ПТГ більше 600 пг/мл ризик смертності зростає вдвічі порівняно з пацієнтами, в яких рівень ПТГ знаходиться в цільових межах [8]. У дослідженнях Levin et al. показано, що поширеність вторинного гіперпаратиреозу (ВГПТ) серед пацієнтів із III-V стадіями ХХН становить 56\% [10].

Висновки. У пацієнтів, які перебувають на діалізі, наявні порушення мінерального обміну, зокрема, кальцію і фосфору. Ці порушення призводять до надмірного вмісту фосфатів. Інгібування цих компенсаційних механізмів потребує подальшого вивчення, оскільки відіграє важливу роль у профілактиці кардіоваскулярних ускладнень у хворих з хронічною хворобою нирок.

хронічна хвороба нирок, серце, кальцій, фосфор, обмін.

Вступ. Незважаючи на досягнення сучасної медицини, хронічна хвороба нирок (ХHН) залишається захворюванням з високим рівнем летальності та тяжким інвалідизуючим станом через швидкий прогрес захворювання, необхідність замісної ниркової терапії та розвиток численних ускладнень. За даними Національного реєстру кількість хворих на XXН, у 2010 році складала 456887 осіб; у 36222 (7,9\%) осіб XXН була виявлена вперше [1]. Кількість пацієнтів, які отримують лікування методами діалізної терапії, згідно з даними USRDS, 3 1988 по 2008 р. збільшилася в 4 рази [2]. В 2010 році методом гемодіалізу в Україні лікувався 4181 хворий [1]. П'ятирічне виживання на діалізі є низь- ким (у Європі - 40,5\%, США - 55,2\% відповідно) і залишається незмінним протягом останнього десятиліття [3]. Але, навіть пацієнти з ранніми стадіями XXН мають низький рівень виживання, приблизно 25\% таких пацієнтів помирають до початку замісної ниркової терапії [4]. Недавній аналіз виявив, що ризик смертності серед діалізних пацієнтів у 6-9 разів вищий порівняно з особами без XXН [5].

Відомо, що пацієнти з XXН частіше вмирають від серцево-судинних причин, ніж від ниркової недостатності. У цих хворих майже в 20 разів вище ризик кардіоваскулярних подій (КВП) [6]. Крім того, навіть для пацієнтів із XXH, що не потребують ниркової замісної терапії, рівень розвитку 
КВП набагато вище, ніж у пацієнтів, що досягають термінальної стадії ниркової недостатності і вимагають ниркової замісної терапії. Але, загальноприйняті фактори серцево-судинного ризику не пояснюють високий рівень смертності від КВП при такому поєднанні [7].

Доведено, що порушення мінерального обміну, зокрема кальцієво-фосфорного гомеостазу, належать до важливих ускладнень, що виникають на ранніх стадіях хронічної хвороби нирок і прогресують із погіршенням функції нирок. У низці досліджень останніх років доведено, що вищі або нижчі від цільових рівні паратгормону (ПТГ), Са, $\mathrm{P}, \mathrm{Ca}^{\star} \mathrm{P}$ продукту тісно корелюють зі зростанням смертності нефрологічних пацієнтів [8, 9]. Так, згідно з даними J. Floege та ін. (2011), у пацієнтів із V стадією XXН та рівнем ПтГ більше 600 пг/мл, ризик смертності зростає вдвічі порівняно з пацієнтами, в яких рівень ПТГ знаходиться в цільових межах [8]. У дослідженнях Levin et al. показано, що поширеність вторинного гіперпаратиреозу (ВГПТ) серед пацієнтів із III-V стадіями XXH становить 56\% [10].

У 2003 році організацією National Kidney Foundation були прийняті рекомендаціії K/DOQI Clinical Practice Guidelines for Bone Metabolism and Disease in Chronic Kidney Disease [11], згідно з якими визначено цільові рівні показників кальцієво-фосфорного обміну залежно від стадії XXН (табл. 1).

Таблиця 1

\section{Цільові значення ПТГ, фосфору і кальцію залежно від стадії XXH згідно рекомендацій NKF - K/DOQI (2003)}

\begin{tabular}{|c|c|c|c|c|c|}
\hline Стадія XXH & ШКФ (мл/Xв/1,73 м²) & $\begin{array}{c}\text { Цільові значення } \\
\text { концентрації ПTT, nr/мл } \\
\text { (пмоль/л) }\end{array}$ & $\begin{array}{c}\text { Цільові значення } \\
\text { концентрації фосфору, } \\
\text { ммоль/л }\end{array}$ & $\begin{array}{c}\text { Цільові значення } \\
\text { концентрації кальцію, } \\
\text { ммоль } / л\end{array}$ & $\begin{array}{c}\text { Цільові значен } \\
\text { ня Са } \times \text { Р продукту, } \\
\text { ммоль } \text { 七 }^{2} / \pi^{2}\end{array}$ \\
\hline III & $30-59$ & $\begin{array}{c}35-70 \\
(3,85-7,70)\end{array}$ & $0,87-1,48$ & $2,10-2,49$ & Нижче 4,4 \\
\hline$N$ & $15-29$ & $\begin{array}{c}70-110 \\
(7,7-12,1)\end{array}$ & $0,87-1,48$ & $2,10-2,49$ & Нижче 4,4 \\
\hline V & $<15$ або діаліз & $\begin{array}{c}150-300 \\
(16,3-33,0)\end{array}$ & $1,13-1,78$ & $2,10-2,37$ & Нижче 4,4 \\
\hline
\end{tabular}

Організацією KDIGO (Kidney Disease Improving Global Outcomes) у 2009 році було введено термін і класифікацію мінеральних та кісткових порушень при хронічній хворобі нирок - XXНМКП [12]. Згідно з рекомендаціями, даний термін повинен застосовуватися за наявності однієї або комбінації таких ознак:

- відхилення від норми біохімічних показників метаболізму кальцію, фосфору, паратгормону і вітаміну D;

- аномалії швидкості кісткового обміну, мінералізації, об'єму кістки, лінійного росту і/або щільності;

- кальцифікації судин та інших м'яких тканин.

Порушення розвиваються при зниженні гломерулярної фільтрації більше ніж на 40\%. При визначенні концепції синдрому CKD-MBD, пов'язаної з вивченням серцево-судинних факторів ризику, враховують три нові ознаки [13]:

- зміна вмісту фосфору;

- відхилення рівня фактора росту фібробластів 23 (FGF23) і білку $\alpha$-Klotho (Klotho);

- наявність судинного кальцинозу.

Численними дослідженнями доведено, що гіперфосфатемія збільшує ризик судинної кальцифікації, що пов'язана з підвищенням AT, гіперкінетичною циркуляцією, збільшенням роботи серця, високим стресом артеріальної стінки [14, 15] і кардіоваскулярною летальністю [16]. Виявлено, що у хворих із гіперфосфатемією порівняно з тими, у яких визначено нормофосфатемію, на $52 \%$ вищий ризик розвитку ішемічної хвороби серця, на $26 \%$ - раптової смерті, на $39 \%$ - цереброваскулярних ускладнень [17].

При ХХН судинний кальциноз (СК) в основному представлений медіальним артеріосклерозом (склероз Менкеберга - Mönckeberg's arteriosclerosis), при якому аморфний мінерал формується в медіальному шарі судин [18]. Вважають, що прискорений розвиток ушкоджень судинної стінки у хворих XXН пов'язано з декількома механізмами, які призводять до розвитку КВС у пацієнтів з ХХН. При цьому, одними з надзвичайно важливих складових патогенезу ускладнень хвороб нирок $€$ порушення мінерального обміну [19].

Отже, можна стверджувати, що застосування гемодіалізу при ХНH обумовило збільшення частоти уражень опорно-рухового апарату, а проведені дослідження, які встановили тісний зв'язок між порушеннями кальцієво-фосфорного обміну, прогресуванням гіперпаратиреозу, серцево-судинними захворюваннями та смертністю хворих на термінальну ХНH, визначили істотне зростання інтересу до вивчення даної проблеми. 
Фосфорно-кальцієвий обмін і його регуляція. В організмі дорослої людини міститься в середньому близько 1-2 кг кальцію (Са), який знаходиться в основному в кістках $(99 \%)$ у формі гідроксиапатиту: 3[Ca3(PO4)2]Ca(OH)2. Решта, що міститься в позаклітинній рідини (ПКР), 60\% представлено непов'язаним з білком ультрафільтрованим Са (здатним проходити через клітинні мембрани), що, в свою чергу, складається з іонізованого (50\%) і комплексованого Са, пов'язаного з такими аніонами, як цитрат, фосфат, сульфат і бікарбонат (10\%) [20]. Решта 40\% Са в ПКР знаходяться в поєднанні з білками (переважно альбуміном). Тільки концентрація іонізованого $\mathrm{Ca}$ $\epsilon$ фізіологічно активною і регульованою. Кальцій кісткової тканини безперервно обмінюється з Са позаклітинної рідини. Реабсорбція кальцію в проксимальних канальцях становить $60-70 \%$ профільтрованого Са, в товстому висхідному відділі петлі Генле - 20-25\%, в дистальних звивистих канальцях $-5-10 \%$, в збірних трубках - 0,5-1\%. В клітину кальцій надходить, мабуть, через кальцієві канали, а з клітин видаляється $\mathrm{Ca} 2+-\mathrm{Na}+-\mathrm{ko}-$ транспортером або Са2+ помпою [21].

Основна частина фосфату (P), як і Са, знаходиться в скелеті (80\%), і лише близько 10\% в скелетних м'язах і внутрішніх органах. Лише незначна фракція $\mathrm{P} \in$ неорганічною і може бути використана для синтезу аденозинтрифосфату
(АТФ). Близько 2/3 загального Р сироватки представлено органічними сполуками (фосфоліпідами) i 1/3 - неорганічним P [22]. В основному P всмоктується пасивно, але $є$ і активний компонент, регульований кальцитріолом (Рис. 1).

У нирках 80\% профільтрований Р реабсорбується в проксимальних канальцях, 10\% - всмоктується в дистальних канальцях і тільки 10\% - виводиться 3 сечею [23]. Надходження Р в клітини проксимальних канальців здійснюється за допомогою Na-P-котранспортеров I і II типів, в значній мірі схожих за будовою. Na-P-котранспортер II типу здатний переносити через апікальну мембрану канальцевих клітин як моно-, так і дивалентні фосфати. Паратгормон (ПТГ) і рівень споживання P регулюють активність Na-P котранспортера II типу. Концентрацію Р сироватки крові регулюють гормони: ПТГ, кальцитріол (КТ) і фактор росту фібробластів 23 (ФРФ23) [24] (Рис.2). Ниркова екскреція $\mathrm{P} \in$ основним регулятором його вмісту в сироватці крові.

Висновки. Таким чином, у пацієнтів, які перебувають на діалізі, наявні порушення мінерального обміну, зокрема, кальцію і фосфору. Ці порушення призводять до надмірного вмісту фосфратів. IHгібування цих компенсаційних механізмів потребує подальшого вивчення, оскільки відіграє важливу роль у профілактиці кардіоваскулярних ускладнень у хворих з хронічною хворобою нирок.

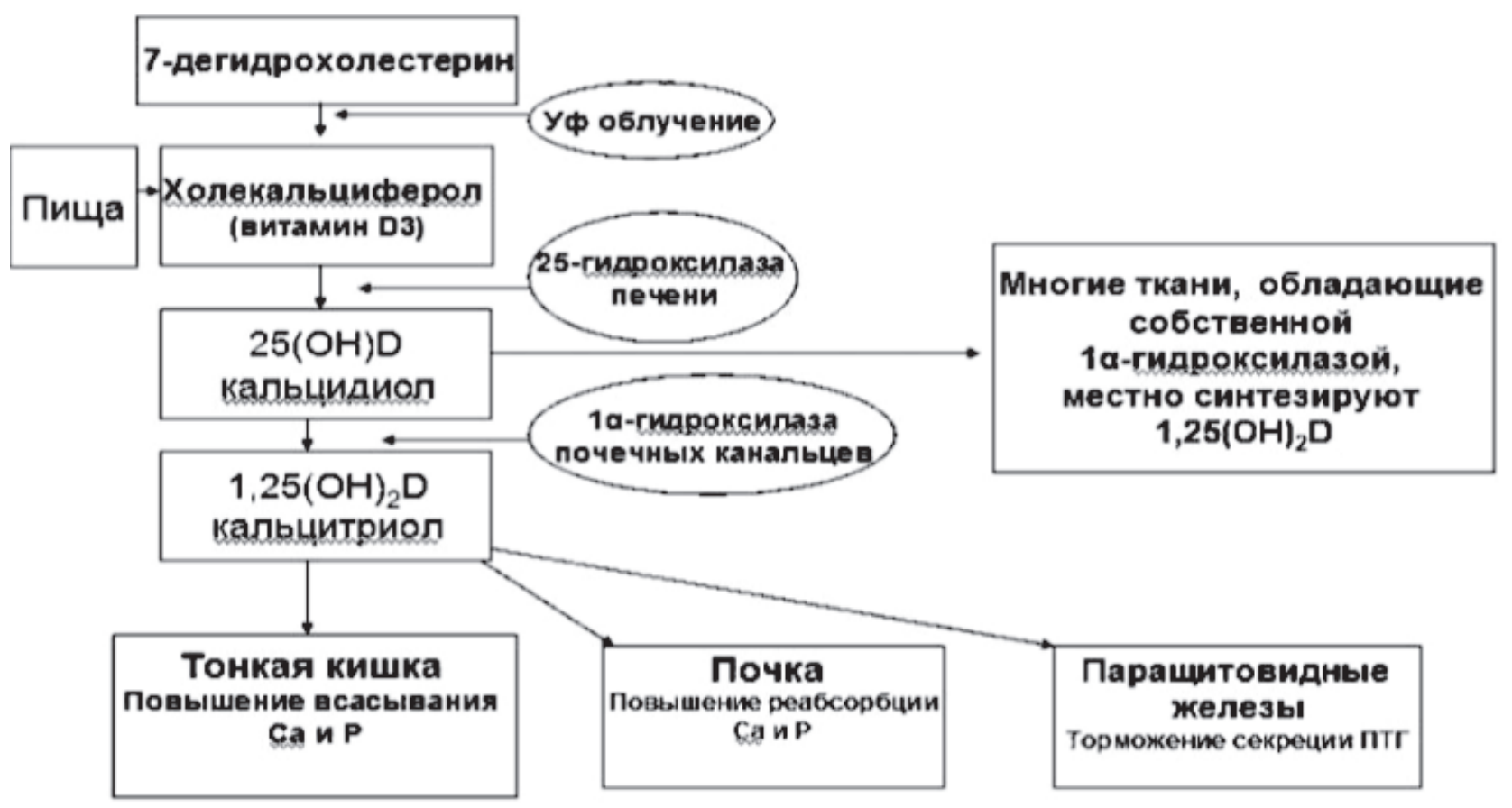

Рис. 1. Утворення та основні ефекти вітаміну D 


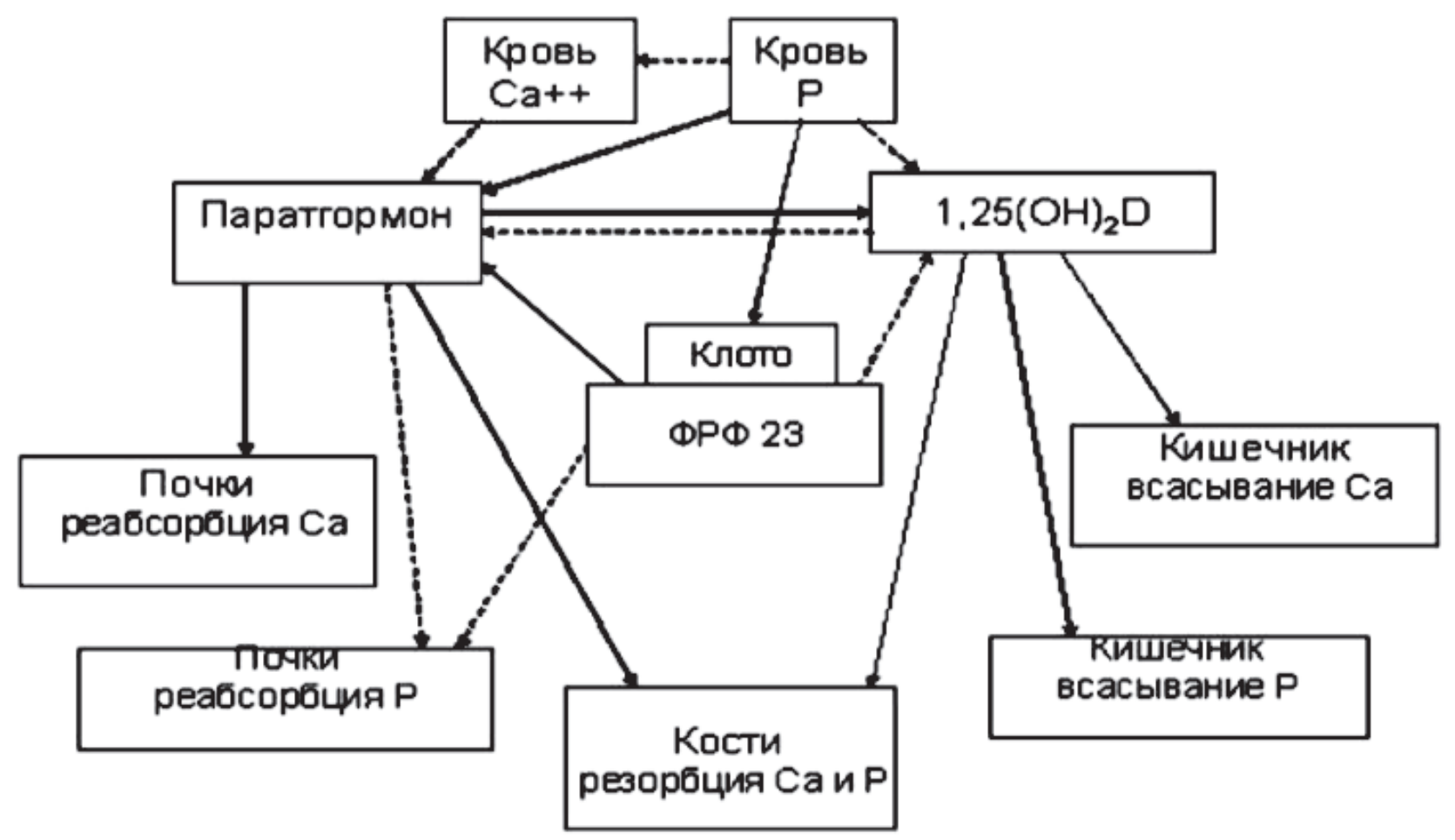

Рис. 2. Схема регуляції фосфорно-кальцієвого балансу (показані основні ефекти гормонів). Са - кальцій, P - фосфат, FGF23 (ФРФ 23) - фактор росту фібробластів 23, 1,25 (ОН)2D - кальцитріол або D-гормон. Стрілки із суцільною лінією - стимулюючий ефект, штриховий - гальмуючий

\section{ЛITЕРАТУРА}

1. Національний реєстр хворих на хронічну хворобу нирок: 2010 рік/Уклад. Н.І. Козлюк, Г.С. Владзієвська, М.В. Кулизький; Державна установа «нститут нефрології АМН України»; гол. ред. М.О. Колесник. - К., 2011. - 89. 40 прим.

2. Meguid E.N. Chronic kidney disease: the global challenge / E.N. Meguid, A.K. Bello // Lancet. 2005. - № 365. - P. 331340.

3. United States Renal Data Systems. USRDS 2007 Annual Data Report: Atlas of EndStage Renal Disease in the United States. Bethesda, MD: National Institute of Health, National Institute of Diabetes and Digestive and Kidney Diseases; 2007.

4. Daly C. Is early chronic kidney disease an important risk factor for cardiovascular disease? A background paper prepared for the UK Consensus Conference on early chronic kidney disease // Nephrol. Dial. Transplant. - 2007. - № 22 (Suppl. 9). - P. 1925.

5. United States Renal Data Systems. USRDS 2005 Annual Data Report: Atlas of EndStage Renal Disease in the United States. Bethesda, MD: National Institute of Health, National Institute of Diabetes and Digestive and Kidney Diseases; 2005.

6. Mendoza J.M., Isakova T., Cai X., Bayes L.Y., Faul C., Scialla J. Inflammation and elevated levels of fibroblast growth factor 23 are independent risk factors for death in chronic kidney disease. // Kidney Int. - 2017. - V. 91. - I. 3. - P. 711-719.

7. Колесник М.О., Лапчинська І.І., Тащук В.К., Дядик O.І., Кулизький М.В. Кардіоваскулярні ускладнення у хворих на хронічну хворобу нирок. / Київ, 2010. - 224 c.

8. Floege J. Serum iPTH, calcium and phosphate, and the risk of mortality in a European haemodialisis population / J. Floege, J. Kim, E. Ireland, C. Chazot, T. Drueke // Nephrol. Dial. Transplant. 2011. - № 26(6). - P. 19481955.

9. Anrann K. Hyperphosphataemia - a silent killer of paitients with renal failure // Nephrol. Dial. Transplant. - 1999. - Vol. 14(9). - P. 20852087.

10. Levin A. Prevalence of abnormal serum vitamin D, PTH, calcium and phosphorus in patients with chronic kidney disease: results of the study to evaluate early kidney disease / Levin A., Bakris G.L., Molitch M. // Kidney Int. - 2007. - № 71. P. 3138.

11. K/DOQI clinical practice guidelines for bone metabolism and disease in chronic kidney disease // Am. J. Kidney Dis. - 2003. - Vol. 42(3). - P. 1201.

12. KDIGO Clinical Practice Guideline for the Diagnosis, Evaluation, Prevention, and Treatment of Chronic Kidney DiseaseMineral and Bone Disorder (CKDMBD) // Kidney Int. — 2009. — 76 (suppl. 113). - S1130.

13. IDF Diabetes Atlas. 2015. - 7th Edition. 
14. Llach F. Hyperphosphatemia in endstage renal disease patients: pathophysiological consequences // Kidney Int. - 1999. - Vol. 73. - P. 3137.

15. Malluche H.H. Understanding and managing hyperphosphatemia in patients with chronic renal disease / Malluche H.H., MonierFaugere M.C. // Clin. Nephrol. - 1999. - Vol. 52. - P. 267277.

16. Ganesh S.K. Association of elevated serum PO4, $\mathrm{Ca}$ PO4 product, and parathyroid hormone with cardiac mortality risk in chronic hemodialysis patients / Ganesh S.K., Stack A.G., Levin N.W., HulbertShearon T., Port F.K. // J. Am. Soc. Nephrol. - 2001. - Vol. 12. - P. 21312138.

17. Jüppner H., Wolf M., Salusky I. FGF23: More than a regulator of renal phosphate handling? / Jüppner H., Wolf M., Salusky I. // Journal of Bone and Mineral Research. - 2010. - Vol. 25. - Issue 10. - P. 20912097.

18. Lim K., Lu T.S., Molostvov G., Lee C. Vascular Klotho deficiency potentiates the development of human artery calcification and mediates resistance to fibroblast growth factor 23 . // Circulation. - 2012. - V. 125. - P. 2243-2255.

19. Chang J.R., Guo J., Wang Y. et al. Intermedin1-53 attenuates vascular calcification in rats with chronic kidney disease by upregulation of a-Klotho. // Kidney Int. - 2016. - V. 89. - P. 586600.

20. Matkovic V, Heaney RP. Calcium balance during human growth: evidence for threshold behavior. Am.J.Clin.Nutr. 1992; 55:992-996. [PubMed: 1570810].

21. Friedman PA. Calcium transport in the kidney. Curr.Opin.Nephrol.Hypertens. 1999; 8:589-595. PubMed: 1054-1222.

22. Reilly RF. The patient with disorders of serum calcium and phosphate. In: Schrier RW (ed). Manual of nephrology. Sixth ed. Philadelphia: Lippincott Williams \& Wilkins; 2005: 61-78.

23. Hoenderop JG, Nilius B, Bindels RJ. Calcium absorption across epithelia. Physiol Rev. 2005; 85:373-422. [PubMed: 15618484].

24. Imel EA, Econs MJ. Fibrous dysplasia, phosphate wasting and fibroblast growth factor 23. Pediatr.Endocrinol.Rev. 2007; 4(Suppl 4):434-439. [PubMed: 17982392].

\section{PЕЗЮME}

\section{НАРУШЕНИЕ МИНЕРАЛЬНОГО ОБМЕНА У ПАЦИЕНТОВ С ХРОНИЧЕСКОЙ БОЛЕЗНЬЮ ПОЧЕК И СЕРДЕЧНО-СОСУДИСТЫМИ ЗАБОЛЕВАНИЯМИ}

\author{
Мойсеенко В.А., Медведев Т.Н. \\ Национальный медицинский университет \\ имени А.А. Богомольца
}

Введение. Известно, что пациенты с ХБП чаще умирают от сердечно-сосудистых причин, чем от по- чечной недостаточности. У этих больных почти в 20 раз выше риск кардиоваскулярных событий (КИПиА) [6]. Кроме того, даже для пациентов с ХБП, не требующие почечной заместительной терапии, уровень развития КИП гораздо выше, чем у пациентов, достигают терминальной стадии почечной недостаточности и требуют почечной заместительной терапии.

Цель. Изучить параллели нарушения минерального обмена у больных с хронической болезнью почек и сердечно-сосудистыми заболеваниями.

Материалы и методы. Обзор современных и зарубежных источников, анализ и обсуждение конкретного клинического случая; методики - описание, анализ, реферирования.

Результаты и их обсуждение. Приведены и проанализированы нарушения минерального обмена, в частности кальциево-фосфорного гомеостаза, относятся к важным осложнений, возникающих на ранних стадиях хронической болезни почек и прогрессируют с ухудшением функции почек. В ряде исследований последних лет доказано, что выше или ниже целевого уровня паратгормона (ПТГ), Са, Р, Са * Р продукта тесно коррелируют с ростом смертности нефрологических пациентов [8, 9]. Так, согласно данным J. Floege и др. (2011), у пациентов с V стадией ХБП и уровнем ПТГ более 600 пг / мл риск смертности возрастает вдвое по сравнению с пациентами, у которых уровень ПТГ находится в целевых пределах [8]. В исследованиях Levin et al. показано, что распространенность вторичного гиперпаратиреоза (ВГПТ) среди пациентов с III-V стадиями ХБП составляет 56\% [10].

Выводы. У пациентов, находящихся на диализе, имеющиеся нарушения минерального обмена, в частности, кальция и фосфора. Эти нарушения приводят к избыточного содержания фосфатов. Ингибирование этих компенсационных механизмов требует дальнейшего изучения, поскольку играет важную роль в профилактике кардиоваскулярных осложнений у больных с хронической болезнью почек.

Ключевые слова: хроническая болезнь почек, сердце, кальций, фосфор, обмен.

\section{SUMMARY}

\section{VIOLATION OF MINERAL EXCHANGE IN PATIENTS WITH CHRONIC KIDNEY DISEASE AND CARDIOVASCULAR DISEASES}

\author{
Moyseyenko V., Medvedev T. \\ Bogomolets National Medical University
}

Introduction. It is known that patients with CKD are more likely to die from cardiovascular causes than from renal failure. These patients have almost 20 times higher risk of cardiovascular events (CVD) [6]. In addition, even for patients with CKD who do not require renal replacement therapy, the rate of CVD is much higher than in patients who reach end-stage renal disease and require renal replacement therapy.

Goal. To study the parallels of mineral metabolism disorders in patients with chronic kidney disease and cardiovascular diseases.

Materials and methods. Review of modern and foreign sources, analysis and discussion of a specific clinical case; methods - description, analysis, abstracting. 
Results and discussion. Disorders of mineral metabolism, in particular calcium-phosphorus homeostasis, are presented and analyzed, are important complications that occur in the early stages of chronic kidney disease and progress with deteriorating renal function. A number of studies in recent years have shown that higher or lower than target levels of parathyroid hormone (PTH), Ca, P, Ca * $P$ product are closely correlated with increasing mortality of nephrological patients $[8,9]$. Thus, according to J. Floege et al. (2011), in patients with stage V CKD and a PTH level greater than $600 \mathrm{pg} / \mathrm{ml}$, the risk of mortality is doubled compared with patients in whom the PTH level is within the target range [8]. In studies by Levin et al. it is shown that the prevalence of secondary hyperparathyroidism (VGPT) among patients with stage III - V CKD is 56\% [10].

Conclusions. Patients on dialysis have disorders of mineral metabolism, in particular calcium and phosphorus. These disorders lead to excessive phosphate content. Inhibition of these compensatory mechanisms requires further study, as it plays an important role in the prevention of cardiovascular complications in patients with chronic kidney disease.

Key words: chronic kidney disease, heart, calcium, phosphorus, metabolism.

\section{АВТОРСЬКА ДОВІДКА}

Мойсеєнко Валентина Олексіївна Національний медичний університет імені О.О. Богомольця, д.м.Н., професор моб.: +380677779249

E-mail: moyseyenko_vo@ukr.net

Мойсеенко Валентина Алексеевна

Национальный медицинский университет имени А.А. Богомольца, д.м.н., профессор моб .: +380677779249

E-mail: moyseyenko vo@ukr.net

\section{Moyseyenko Valentyna}

Bogomolets National Medical University, MD, Professor

mob .: +380677779249

E-mail: moyseyenko vo@ukr.net

\section{Медведєв Тарас Миколайович}

Національний медичний університет імені

О.О. Богомольця, ФПЛЗСУ

моб.: +380689964177

E-mail: taras.allo2020@gmail.com

Медведев Тарас Николаевич

Национальный медицинский университет имени А.А. Богомольца, ФПЛЗСУ

моб .: +380677779249

E-mail: taras.allo2020@gmail.com

Medvedyev Taras

Bogomolets National Medical University

моб .: +380689964177

E-mail: taras.allo2020@gmail.com

Стаття надійшла до редакції 3.11.20 p. 